\title{
THE RELATIONSHIP BETWEEN SELECTED MACROECONOMIC INDICATORS AND VOLUME OF MORTGAGE LOANS IN THE VISEGRAD GROUP COUNTRIES
}

\author{
[Vzt'ah vybraných makroekonomických ukazovatel'ov a objemu hypotekárnych \\ úverov v krajinách V4]
}

\author{
Helena Rudinská ${ }^{1}$, Petr Strejěek $^{2}$ \\ ${ }^{1}$ Mendelova univerzita v Brně, Provozně ekonomická fakulta, Zemědělská 1, 61300 Brno \\ Email: helenarudinska@gmail.com \\ ${ }^{2}$ Mendelova univerzita v Brně, Provozně ekonomická fakulta, Zemědělská 1, 61300 Brno \\ Email: strejcek@node.mendelu.cz
}

\begin{abstract}
The main aim of this paper is to test the impact of the selected macroeconomic indicators and to define the indicators that have the largest influence on the mortgage credit market in the Slovak Republic, the Czech Republic, Poland and Hungary from 2006 to 2016. We choose this particular group of countries because these countries are close, both geographically and economically, and information about them is easily accessible. The individual data are taken quarterly and we obtain them from the websites of national banks, from hypo.org, oecd.org and the Eurostat statistical database of the European Union. With the purpose to fulfill the stated goal, we examine existence and character of relationship between the selected macroeconomic variables and the volume of mortgage loans by the correlation analysis. Macroeconomic indicators for the correlation analysis are inflation rates, unemployment rates and mortgage loans interest rates. The results show that there is a positive correlation between mortgage loans and mortgage loans interest rates in the Slovak and Czech Republic. The results also confirm the positive dependence of the relationship between mortgage loans interest rates and the inflation rates in Poland and the Slovak Republic.
\end{abstract}

Keywords: correlation analysis, inflation, interest rate, mortgage loans, Visegrad group.

JEL classification: G21

Doručeno redakci: 5.4.2018; Recenzováno: 20.4.2018; 9.5.2018; Schváleno k publikování: 13.6.2018

\section{Úvod}

Hypotekárne úvery majú nezastupitel'né miesto vo väčšine krajín na svete. Ich úlohou je zabezpečit' financovanie nehnutel'ností a rôznych investícií, ktoré sú spojené s bývaním. Prirodzenou potrebou človeka v spoločnosti je zaobstarat' si bývanie podl'a vlastných predstáv či už prostredníctvom prenájmu, alebo vlastníctvom bytu, či domu. Problém, ktorý je spojený $\mathrm{s}$ bývaním $\mathrm{v}$ dnešnej dobe, nie je nedostatok nehnutel'ností, ale predovšetkým nedostatok finančných zdrojov. S rastom zadlženosti domácností sa stretávame $\mathrm{v}$ dnešnej dobe čoraz častejšie, pretože obyvatel'stvo nie je schopné splácat' svoje dlhy. S tým nepriamo súvisia aj úrokové sadzby hypotekárnych úverov, ktoré pretrvávajú na nízkej úrovni od roku 2015 a v súčasnosti neustále klesajú. Jednou z príčin poklesu úrokový sadzieb je aj vzájomná konkurencia $\mathrm{v}$ bankovom sektore $\mathrm{v}$ jednotlivých krajinách. Najviac využívaným prostriedkom na financovanie bývania je hypotekárny úver, ktorý je aj ústrednou témou tohto vedeckého článku.

Motívom, prečo bola vybraná táto téma, je práve to, že hypotekárne úvery sú ekonomickou pákou, pomocou ktorej sa merajú rôzne indikátory napr. spokojnost' domácnosti. Ide o aktuálnu tému, či už kvôli spomínaným nízkym úrokovým sadzbám, alebo neustále rastúcemu záujmu o hypotekárne úvery. Vlády podporujú hypotekárne úvery pre mladých, kde pri 
splnení určitého príjmového limitu môžu získat' štátny príspevok pre mladých. Dôvod, ktorý viedol k výberu zoskupenia Vyšehradskej štvorky, je ten, že tieto krajiny sú si blízke, či už z geografického pohl'adu, alebo ekonomického myslenia. Zároveň sú ovel'a dostupnejšie informácie o týchto 4 krajinách a taktiež keby si chcel mladý človek vybavovat' hypotekárny úver zo zahraničia, vyberie si jednu z týchto krajín, pretože ide o susedné krajiny a ako už bolo povedané, vel'mi podobné v ekonomickom zmýšl’aní.

Z národohospodárskeho hl'adiska sú hypotekárne úvery na kvalitnom hypotekárnom trhu známkou fungujúcich ekonomík. Poskytovanie úverov pomáha podporovat' investície v jednotlivých krajinách, čo dobre vplýva na rast ekonomiky. Teda hypotekárne úvery sú akýmsi indikátorom ekonomiky. Zároveň isté výkyvy v raste ekonomiky môžu signalizovat' aj problémy so stavom hypotekárneho trhu. Otázne je do akej „ideálnej“ miery by mal byt' hypotekárny trh regulovaný. V prípade, že by trh s hypotekárnymi úvermi nebol regulovaný mohlo by dochádzat' $\mathrm{k}$ nafukovaniu hypotekárneho trhu a $\mathrm{k}$ vytvoreniu tzv. hypotekárnej bubliny. Zásah centrálnej banky do trhu s hypotekárnym úvermi ovplyvní a stlmí vel'koobjemné poskytovanie úverov. Tento zásah môže byt' prevedený napríklad zvýšením úrokových sadzieb alebo znížením LTV pomeru.

Jedným z príkladov zlyhania hypotekárneho trhu môže byt' Lehman Brothers v USA v roku 2008. Uvedená banka vo svojich aktívach držala vel'mi rizikové finančné produkty. Pokles ceny aktív len o pár \% by mal za následok bankrot Lehman Brothers. Už v polovici roku 2008 sa objavovali hlasy, ktoré poukazovali na to, že na trhu s podradnými hypotekárnymi úvermi vzniká kríza, na ktorú Lehman Brothers nereagovali. Rekordné straty Lehman Brothers rástli a aktíva sa už nepredávali tak ako kedysi, preto Lehman Brothers požiadala o ochranu pred veritel'mi. Ked' už všetky pokusy o záchranu zlyhali, vedenie Lehman Brothers sa obrátilo na štát, chcelo po centrálnej banke (FED) aby povolilo Lehman Brothers transformáciu na komerčnú banku. FED túto požiadavku neschválil a vláda zvolala stretnutie do newyorského sídla FED-u, na ktorom chceli presvedčit' banky, aby vytvorili z vlastných peňazí fond, ktorý zlé aktíva Lehman Brothers odkúpi a zdravú banku potom predajú. Tento návrh však neprešiel pretože aj iné banky neboli na tom z finančného hl'adiska dobre. Lehman Brothers spadla do bankrotu a britská Barclays odkúpila za 1,75 miliárd dolárov investičnú divíziu skrachovanej banky. Stuchlík (2009)

Primárnym ciel'om tohto článku bolo identifikovat' vplyv príslušných vybraných veličín na trh s hypotekárnymi úvermi, v Slovenskej republike, Českej republike, Pol'skej a Mad'arskej republike za obdobie 2006 až 2016. Pre splnenie stanoveného ciel'a, bola skúmaná existencia vzt’ahu vybraných makroekonomických veličín a objemu hypotekárnych úverov za pomoci využitia ekonometrických metód. Za makroekonomické ukazovatele boli zvolené príslušne veličiny miera inflácie, miera nezamestnanosti, úroková miera hypotekárnych úverov.

Prvá kapitola tohto článku bola zameraná na metodiku, ktorá popisovala využitie jednotlivých ekonometrických metód, ktoré sú potrebné pre splnenie stanoveného ciel'a. Zároveň v prvej kapitole boli špecifikované dáta, $\mathrm{s}$ ktorými sa d’alej pracovalo. Druhá kapitola tohto článku sa venovala samotnej korelačnej analýze. Nasledujúca kapitola obsahovala výsledky a diskusiu, kde budú rozobrané a adekvátne okomentované zistené výsledky z korelačnej analýzy. Posledná čast' sa venovala záveru, kde boli zosumarizované všetky zistené výsledky a poznatky a zodpovedanie stanoveného ciel'a. 


\section{Metodika a dáta}

Pri výpočte korelačnej analýzy dopadu makroekonomických ukazovatel'ov na hypotekárny trh, bola skúmaná závislost' medzi objemom hypotekárnych úverov a skúmanými makroekonomickými ukazovatel'mi mierou nezamestnanosti, mierou inflácie a úrokovou mierou hypotekárnych úverov. Objem hypotekárnych úverov bol vyjadrený v percentuálnej zmene objemu hypotekárnych úverov. Ostatné makroekonomické ukazovatele boli vyjadrené v \%. S ohl'adom na dostupnost' dát boli využité údaje makroekonomických premenných so štvrt'ročnou frekvenciou časových rád, vyjadrené ako index, zmena oproti rovnakému štvrt'roku predchádzajúceho roku. Táto forma vyjadrenia je výhodná, z toho dôvodu, že eliminuje vplyv sezónnosti. Počet pozorovaní časových rád $\mathrm{T}=44$, zodpovedá sledovaným štvrt'rokom od 1. štvrt'roku 2006 do 4. štvrt'roku 2016. Všetky použité údaje boli získané z internetových stránok národných bánk, z internetových stránok hypo.org, oecd.org a štatistickej databázy Európskej únie - Eurostat. Každá jednotlivá makroekonomická veličina je vybraná z takej databázy, kde sú k dispozícií údaje o všetkých 4 krajinách V4, je to z dôvodu aby boli jednotné údaje, rovnaká metodika výpočtu. Celá druhá kapitola Korelačná analýza dopadu makroekonomických ukazovatel'ov na hypotekárny trh bola vytvorená s využitím programov Gretl a Microsoft Excel.

Korelačná analýza bola využitá k zisteniu existencie a závislosti medzi dvoma alebo viacerými makroekonomickými ukazovatel'mi. Korelačná analýza je štatistická metóda, ktorá sa zaoberá lineárnymi závislost’ami, predovšetkým sa zameriava na tesnost' vzt'ahu medzi ukazovatel'mi. Korelačná analýza bola prevedená za pomoci Pearsonovho koeficientu korelácie r.

Za premennú Y (vysvetl’ovaná, závislá premenná) vystupovali hodnoty objemu hypotekárnych úverov. Premennú X (vysvetl'ujúca, nezávislá premenná) predstavovali hodnoty makroekonomických ukazovatel'ov (miera nezamestnanosti, miera inflácie, úrokové sadzby hypotekárnych úverov).

Preukázatel'nost' korelačného koeficientu bola považovaná za dostatočnú od hodnoty 0,7 v absolútnom vyjadrení. Vel'mi tesnú závislost' bola identifikovat' hodnota korelačného koeficientu väčšia alebo rovná $0,8 \mathrm{v}$ absolútnom vyjadrení.

Za pomoci korelačného koeficientu bola zostrojená korelačná matica pre každú jednu krajinu z Vyšehradskej skupiny.

\section{Korelačná analýza dopadu makroekonomických ukazovatel'ov na hypotekárny trh}

$\mathrm{V}$ tejto kapitole bola prevedená korelačná analýza medzi indikátormi hypotekárneho trhu a makroekonomickými faktormi. Aby objem hypotekárnych úverov v grafickom vyjadrení nemal rastúcu tendenciu a nevyskytoval sa istý rastúci trend, $z$ tohto dôvodu bol objem hypotekárnych úverov prepočítaný na \%, ktoré vyjadrujú zmenu rastu alebo poklesu hypotekárnych úverov v rovnakom štvrt'roku predchádzajúceho roku.

Ako prvé boli znázornené závislosti objemu hypotekárnych úverov v jednotlivých krajinách V4, SR_HU1, CR_HU1, PR_HU1, MR_HU1, mierou nezamestnanosti (MN), mierou inflácie (MI) a úrokovou sadzbou hypotekárnych úverov (US). Následne boli vypočítané korelačné koeficienty pre všetky krajiny Vyšehradskej štvorky a bude vytvorená korelačná matica $\mathrm{s}$ výstupmi zo štatistického softwaru Gretl. 


\section{Závislost' objemu HÚ (\% zmena) na makroekonomických ukazovatel’och}

\section{Slovenská republika}

Obrázok 1: Závislost’ objemu hypotekárnych úverov (\% zmena) na vývoji miery inflácie, miery nezamestnanosti a vývoji úrokových sadzieb v Slovenskej republike
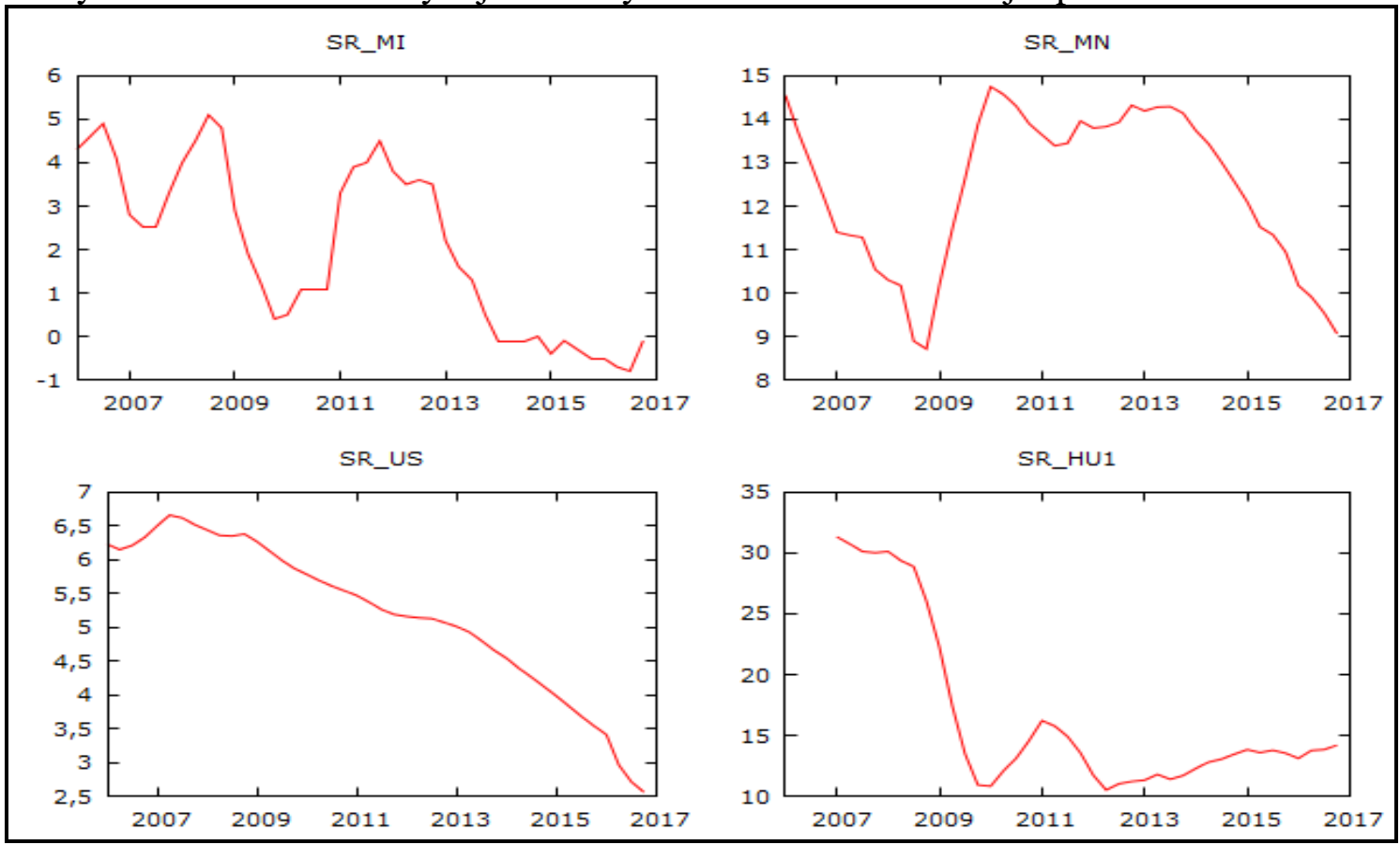

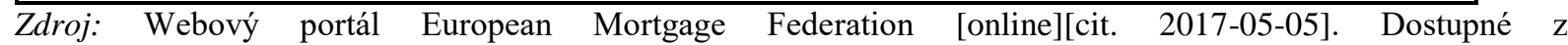
<http://www.hypo.org/DocShareNoFrame/docs/3/EKNDCAFCKCMADJMOIHFKNOHNPDB39DBYBNTE4Q /EMF/Docs/DLS/2007-00106.pdf> (a-k)

Webový portál OECD [online][cit. 2017-05-05]. Dostupné z <https://data.oecd.org/unemp/unemploymentrate.htm>

Webový portál OECD [online][cit. 2017-05-05]. Dostupné z <https://data.oecd.org/price/inflation-cpi.htm>

Objem hypotekárnych úverov Slovenskej republiky sa zvyšoval, ale s menšími percentuálnymi prírastkami po celé sledované obdobie (Obrázok č. 1). Postupné znižovanie prírastku objemu hypotekárnych úverov bolo možné pozorovat' od prelomu rokov 2008 a 2009. Približne od konca roku 2012 objem hypotekárnych úverov rástol viac ako v predchádzajúcom roku rovnakého štvrt'roku. V 4. štvrt'roku 2016 objem hypotekárnych úverov predstavoval rast $14,19 \%$ oproti predchádzajúcemu roku rovnakého štvrt'roku. Úrokové sadzby hypotekárnych úverov postupne klesali. Priemerná úroková sadzba hypotekárnych úverov sa na konci roku 2016 pohybovala okolo hodnoty 2,56\%. Miera nezamestnanosti sa približne od roku 2014 začínala znižovat'. V súčasnosti sa jej hodnota nachádzala na úrovni 9,06 \%, vd’aka ekonomickému vývoju a politickej situácií v Slovenskej republike. Z pohl'adu vývoja miery inflácie sa Slovenská republika nachádzala v deflácií $0,1 \%$, na konci sledovaného roku 2016.

Tabul'ka 1: Korelačná matica pre Slovenskú republiku

\begin{tabular}{|l|l|l|l|l|}
\hline SR_MI & SR_MN & SR_US & SR_HU1 & \\
\hline $\mathbf{1 , 0 0 0 0}$ & $-0,0332$ & 0,7133 & 0,5084 & SR_MI \\
\hline & $\mathbf{1 , 0 0 0 0}$ & 0,0851 & $-0,6206$ & SR_MN \\
\hline & & $\mathbf{1 , 0 0 0 0}$ & 0,6200 & SR_US \\
\hline & & & $\mathbf{1 , 0 0 0 0}$ & SR_HU1 \\
\hline
\end{tabular}

Zdroj: Gretl 
Z tabul'ky č. 1 pre Slovenskú republiku vyplýva, že najsilnejšiu koreláciu dosahoval vzt’ah medzi mierou inflácie a úrokovými sadzbami hypotekárnych úverov, 0,7133. Táto hodnota korelačného koeficientu predstavovala pozitívnu koreláciu, s rastom miery inflácie rastú aj úrokové sadzby hypotekárnych úverov. Splňuje stanovené kritérium preukázatel'nosti 0,7 . Druhou najsilnejšou pozitívnou koreláciou bol vzt’ah medzi úrokovými sadzbami a objem hypotekárnych úverov. S rastom úrokovej sadzby rastie aj \% zmena objemu hypotekárnych úverov oproti predchádzajúcemu roku toho istého štvrt'roku. Najsilnejšou negatívnou koreláciou bol vzt’ah medzi mierou nezamestnanosti a objemom hypotekárnych úverov, 0,6206. S rastom miery nezamestnanosti klesá percentuálna zmena objemu hypotekárnych úverov.

\section{Česká republika}

Obrázok 2: Závislost’ objemu hypotekárnych úverov (\% zmena) na vývoji miery inflácie, miery nezamestnanosti a vývoji úrokových sadzieb v Českej republike
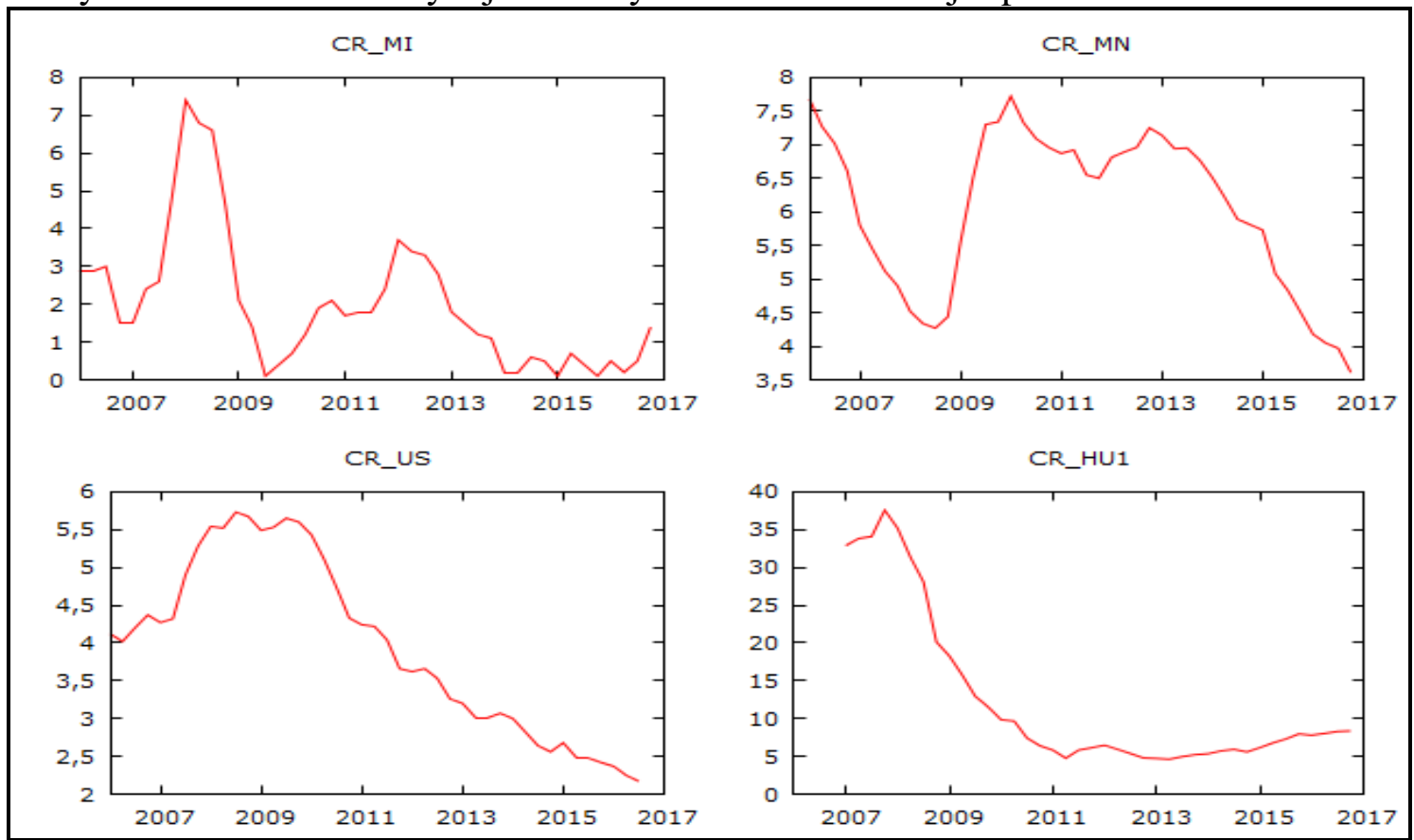

Zdroj: $\quad$ Webový portál European Mortgage Federation $\quad$ [online][cit. 2017-05-05]. Dostupné z <http://www.hypo.org/DocShareNoFrame/docs/3/EKNDCAFCKCMADJMOIHFKNOHNPDB39DBYBNTE4Q /EMF/Docs/DLS/2007-00106.pdf > (a-k)

Webový portál OECD [online][cit. 2017-05-05]. Dostupné z <https://data.oecd.org/unemp/unemploymentrate.htm>

Webový portál OECD [online][cit. 2017-05-05]. Dostupné z <https://data.oecd.org/price/inflation-cpi.htm>

Podobný stav percentuálnej zmeny hypotekárnych úverov oproti predchádzajúcemu roku toho istého štvrt'roku ako bol v Slovenskej republike, je aj v Českej republike. Objem hypotekárnych úverov rástol počas celého sledovaného obdobia, avšak s menšími percentuálnymi prírastkami oproti predchádzajúcemu roku rovnakého štvrt'roku. (Obrázok č. 2) V 4. štvrt'roku predstavoval rast hypotekárnych úverov o 8,36 \% oproti minulému roku 2015 rovnakého 4. štvrt'roku. . Hodnota priemerných úrokových sadzieb hypotekárnych úverov sa pohybovala na úrovni $2,17 \%$. Najnižšiu mieru nezamestnanosti spomedzi krajín V4 dosahovala práve Česká republika, na konci 4. štvrt'roku 2016 bola hodnota miery nezamestnanosti 3,61\%. Začiatkom roku 2016 sa podarilo zvýšit' mieru inflácie z približne $0 \%$ hladiny na $1,4 \%$. 
Tabul'ka 2: Korelačná matica pre Českú republiku

\begin{tabular}{|l|l|l|l|l|}
\hline CR_MI & CR_MN & CR_US & CR_HU1 & \\
\hline $\mathbf{1 , 0 0 0 0}$ & $-0,2780$ & 0,5582 & 0,6308 & CR_MI \\
\hline & $\mathbf{1 , 0 0 0 0}$ & 0,1336 & $-0,4830$ & CR_MN \\
\hline & & $\mathbf{1 , 0 0 0 0}$ & 0,6113 & CR_US \\
\hline & & & $\mathbf{1 , 0 0 0 0}$ & CR_HU1 \\
\hline
\end{tabular}

Zdroj: Gretl

Pre Českú republiku bolo možné na základe dosiahnutých výsledkov korelačnej matice posúdit', že najsilnejší vzt’ah bol medzi mierou inflácie a objemom hypotekárnych úverov, 0,6308. Táto hodnota koeficientu korelácie predstavovala pozitívnu lineárnu koreláciu. S rastom miery inflácie rástla aj percentuálna zmena objemu hypotekárnych úverov oproti predošlému roku rovnakého štvrt'roku. Ďalšou pomerne významnou hodnotou korelácie bola 0,6113. Čo predstavoval vzt’ah medzi úrokovými sadzbami a hypotekárnymi úvermi, bola to pozitívna lineárna korelácia, ktorá taktiež nesplňuje hodnotu preukázatel’nosti 0,7 .

\section{Pol'ská republika}

Obrázok 3: Závislost’ objemu hypotekárnych úverov (\% zmena) na vývoji miery inflácie, miery nezamestnanosti a vývoji úrokových sadzieb v Pol'skej republike
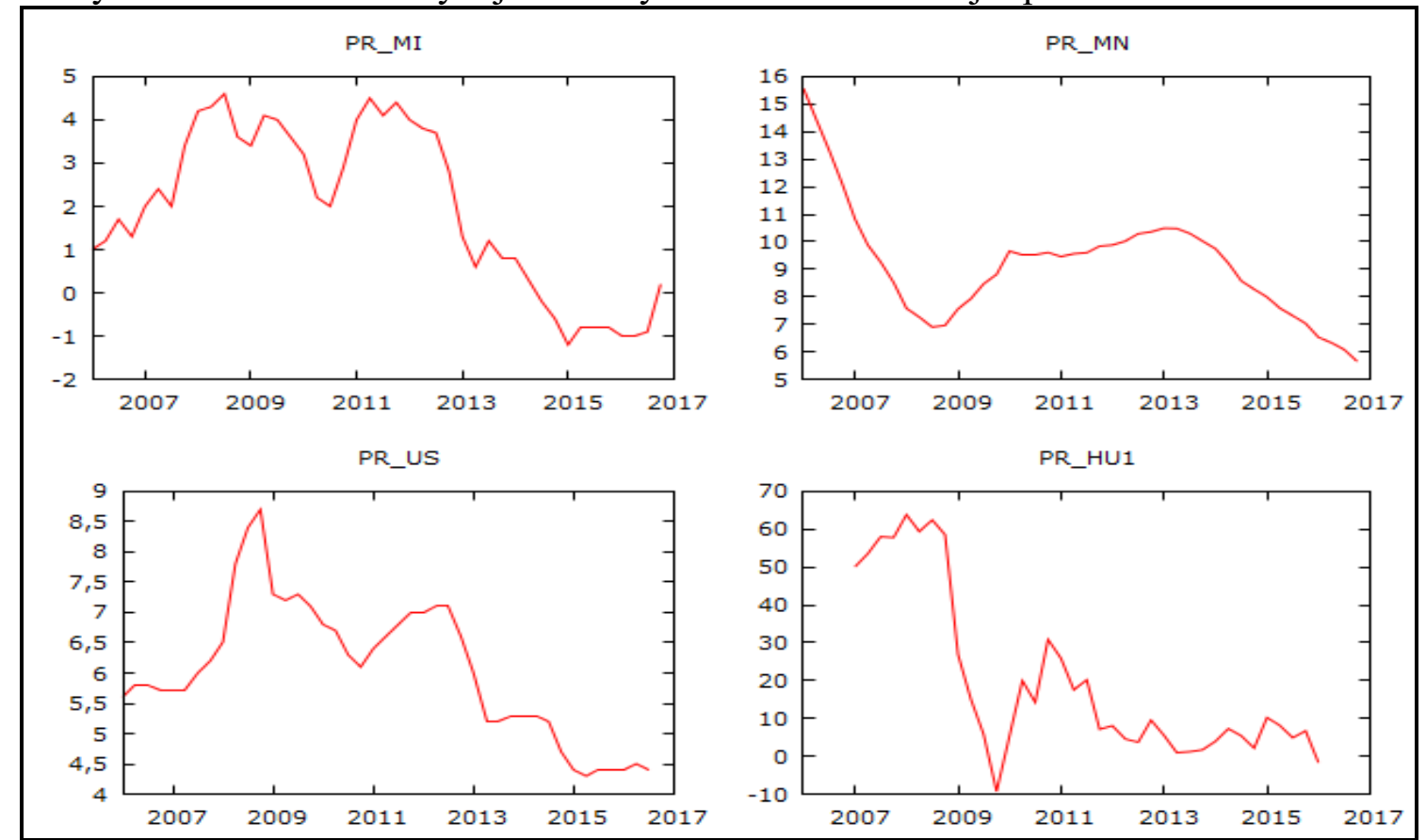

Zdroj: Webový portál European Mortgage Federation [online][cit. 2017-05-05]. Dostupné z <http://www.hypo.org/DocShareNoFrame/docs/3/EKNDCAFCKCMADJMOIHFKNOHNPDB39DBYBNTE4Q /EMF/Docs/DLS/2007-00106.pdf> (a-k)

Webový portál OECD [online][cit. 2017-05-05]. Dostupné z <https://data.oecd.org/unemp/unemploymentrate.htm>

Webový portál OECD [online][cit. 2017-05-05]. Dostupné z <https://data.oecd.org/price/inflation-cpi.htm>

Z Obrázka č. 3 pre Pol'skú republiku vyplýva, že najvyšší prírastok objemu hypotekárnych úverov bol dosiahnutý v 3. štvrt'roku 2009, 62,41 \%. V Pol'skej republike bolo možné pozorovat' pokles objemu hypotekárnych úverov oproti predchádzajúcemu roku rovnakého štvrt'roku o -9,29 \% v 4. štvrt'roku 2009. V 1. štvrt'roku 2016 dosahovala Pol'ská republika d'alší pokles objemu hypotekárnych úverov o $-1,68 \%$. Priemerná úroková sadzba hypotekárnych úverov sa v 4. štvrt'roku 2016 nachádzala na úrovni 4,40 \%. Miera 
nezamestnanosti od začiatku roku 2006 až po rok 2009 výrazne klesala, no v priebehu roku 2009 nastal zlom a miera nezamestnanosti sa v Pol'skej republike mierne zvyšovala. Zmena v pokles miery nezamestnanosti nastala začiatkom roku 2013. V štvrtom štvrt'roku 2016 sa miera nezamestnanosti v Pol'skej republike nachádzala na úrovni 5,65 \%. Od 3. štvrt'roku 2014 do 3 štvrt'roku 2016 mala Pol'ská republika problém s defláciou, ale v 4. štvrt'roku sa už miera inflácie pohybovala na úrovni $0,2 \%$.

Tabul'ka 3: Korelačná matica pre Pol'skú republiku

\begin{tabular}{|l|l|l|l|l|}
\hline PR_MI & PR_MN & PR_US & PR_HU1 & \\
\hline $\mathbf{1 , 0 0 0 0}$ & 0,1633 & 0,9040 & 0,4228 & PR_MI \\
\hline & $\mathbf{1 , 0 0 0 0}$ & $-0,0058$ & $-0,2562$ & PR_MN \\
\hline & & $\mathbf{1 , 0 0 0 0}$ & 0,4186 & PR_US \\
\hline & & & $\mathbf{1 , 0 0 0 0}$ & PR_HU1 \\
\hline
\end{tabular}

Zdroj: Gretl

Z tabul'ky č. 3 bolo možné vydedukovat' najsilnejšiu koreláciu pre Pol'skú republiku vo vzt’ahu medzi mierou inflácie a úrokovými sadzbami hypotekárnych úverov, 0,9040. Hodnota párového korelačného koeficientu vyjadrovala silnú pozitívnu lineárnu koreláciu a vel'mi významnú a tesnú závislost'. Taktiež spĺňala hodnotu stanovenej preukázatel'nosti 0,7 . $\mathrm{S}$ rastom miery inflácie rástli aj úrokové sadzby hypotekárnych úverov a naopak. Druhou najsilnejšou ale nie až tak významnou pozitívnou hodnotou korelácie bol vzt'ah miery inflácie a objemu hypotekárnych úverov, 0,4228 . S rastom miery inflácie rástla aj percentuálna zmena objemu hypotekárnych úverov a naopak s poklesom miery inflácie klesala aj percentuálna zmena objemu hypotekárnych úverov.

\section{Mad'arská republika}

Obrázok 4: Závislost’ objemu hypotekárnych úverov (\% zmena) na vývoji miery inflácie, miery nezamestnanosti a vývoji úrokových sadzieb v Mad'arskej republike

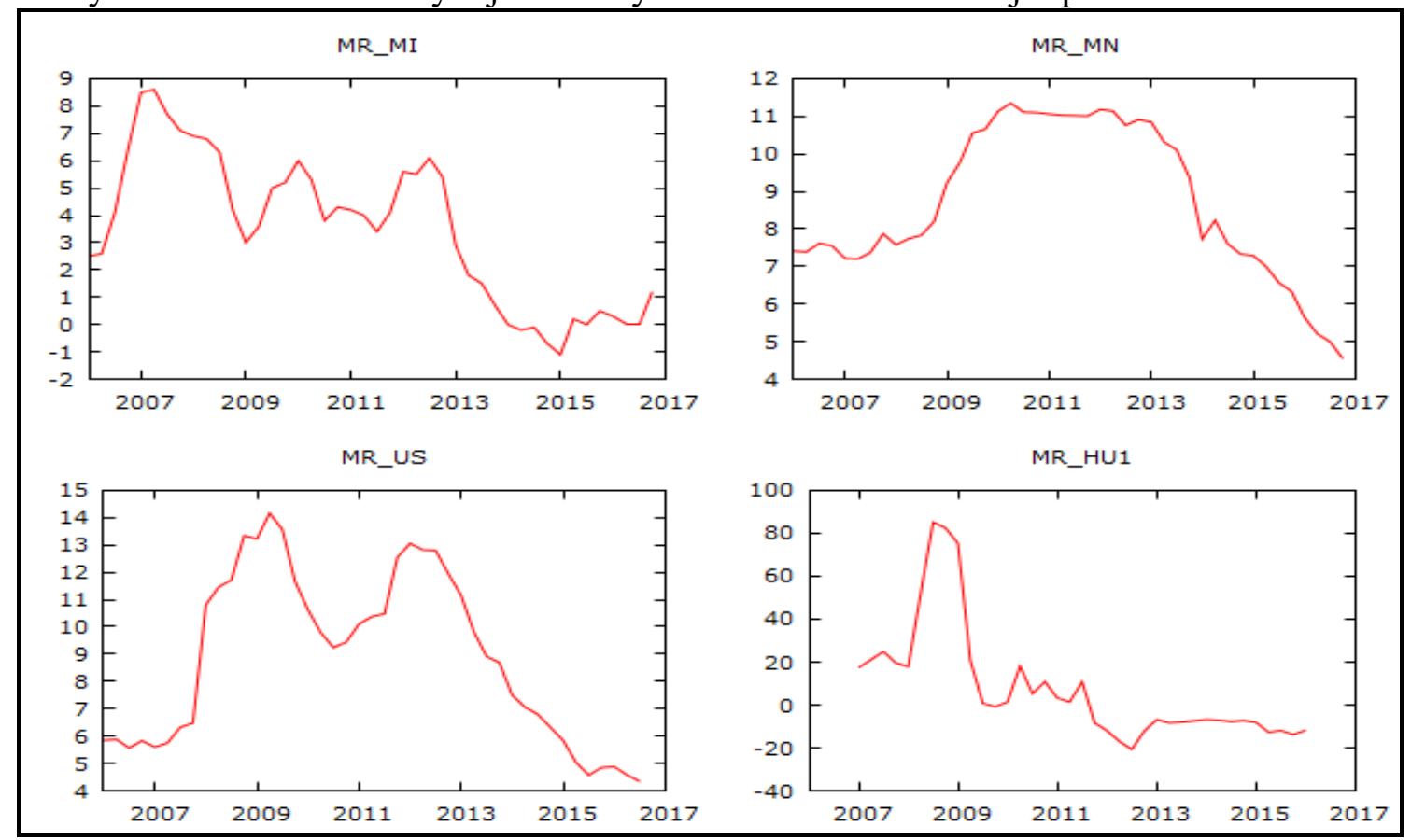

Zdroj: Webový portál European Mortgage Federation [online][cit. 2017-05-05]. Dostupné z <http://www.hypo.org/DocShareNoFrame/docs/3/EKNDCAFCKCMADJMOIHFKNOHNPDB39DBYBNTE4Q /EMF/Docs/DLS/2007-00106.pdf> (a-k) 
Webový portál OECD [online][cit. 2017-05-05]. Dostupné z <https://data.oecd.org/unemp/unemploymentrate.htm>

Webový portál OECD [online][cit. 2017-05-05]. Dostupné z <https://data.oecd.org/price/inflation-cpi.htm>

Obrovský prepad a teda aj najväčší pokles v objeme hypotekárnych úverov oproti rovnakému štvrt'roku predchádzajúceho roku bol pozorovatel'ný na konci roku 2008 a začiatku roku 2009, kedy z prírastku $85,11 \%$ poklesol na prírastok 0,77 \% a d'alší štvrt'rok bol už v znamení poklesu objemu hypotekárnych úverov o $-0,90 \%$. (Obrázok č. 4) Najväčší pokles objemu hypotekárnych úverov bol identifikovaný v 3. štvrt'roku 2012, - 20,70\%. V prvom štvrt'roku 2016 dosahovala Mad'arská republika pokles o - 11,82 \% oproti prvému štvrt'roku 2015. Pokles úrokových sadzieb bol dlhodobo pozorovatel'ný od roku 2012 až po koniec sledovaného obdobia. Priemerná úroková sadzba hypotekárnych úverov v 3. štvrt'roku 2016 sa pohybovala na úrovni 4,34\%. Miera nezamestnanosti mala tak ako v ostatných krajinách Vyšehradskej štvorky klesajúcu tendenciu a v súčasnosti jej hodnota dosahovala úroveň $4,55 \%$, čo bola druhá najnižšia miera nezamestnanosti v porovnaní s krajinami V4. Hodnota miery inflácie bola $1,2 \%$, čo bola taktiež druhá ale najvyššia hodnota v porovnaní s krajinami V4.

Tabul'ka 4: Korelačná matica pre Mad'arskú republiku

\begin{tabular}{|l|l|l|l|l|}
\hline MR_MI & MR_MN & MR_US & MR_HU1 & \\
\hline $\mathbf{1 , 0 0 0 0}$ & 0,2707 & 0,3942 & 0,4023 & MR_MI \\
\hline & $\mathbf{1 , 0 0 0 0}$ & 0,7129 & $-0,1601$ & MR_MN \\
\hline & & $\mathbf{1 , 0 0 0 0}$ & 0,3079 & MR_US \\
\hline & & & $\mathbf{1 , 0 0 0 0}$ & MR_HU1 \\
\hline
\end{tabular}

Zdroj: Gretl

Na základe dosiahnutých výsledkov korelačnej matice pre Mad'arskú republiku bolo možné tvrdit', že najsilnejšia korelácia bola objavená vo vzt’ahu medzi mierou nezamestnanosti a úrokovými sadzbami hypotekárnych úverov, 0,7129. Jedná sa o významnú, ale nie vel'mi tesnú lineárnu závislost'. S rastúcou mierou nezamestnanosti rástli aj úrokové sadzby hypotekárnych úverov a naopak. Splňovala kritérium preukázatel'nosti. Ďalšou pozitívnou hodnotou korelačného koeficientu bol vzt'ah medzi mierou inflácie a objemom hypotekárnych úverov, 0,4023. Čo predstavuje nie vel’mi významnú a tesnú lineárnu závislost'.

Tret'ou najsilnejšou pozitívnou koreláciou bol vzt'ah medzi mierou inflácie a úrokovými sadzbami hypotekárnych úverov, 0,3942. Avšak ani jedna z príslušných hodnôt nespíňala stanovenú hodnotu preukázatel'nosti 0,7 .

\section{Výsledky a diskusia}

Za pomoci využitia korelačnej analýzy pri skúmaní korelácie v kapitole 2, teda závislosti objemu hypotekárnych úverov (\% zmena) a makroekonomickými ukazovatel'mi, bola objavená najsilnejšia závislost' vo vzt’ahu medzi mierou inflácie a úrokovými sadzbami hypotekárnych úverov v Pol'skej republike. Hodnota korelačného koeficientu je 0,9040 a predstavovala vel'mi silnú a tesnú pozitívnu závislost'. S rastom úrokových sadzieb hypotekárnych úverov rástli aj miera inflácie. Pomerne vysoký koeficient korelácie pri rovnakom vzt'ahu miery inflácie a úrokových sadzieb hypotekárnych úverov vyšiel aj v Slovenskej republike. Aj v súčasnosti bol stav nízkych úrokových sadzieb a čoraz viac l’udí žiadalo o hypotekárny úver, pretože sú vel'mi výhodné a nízke úrokové sadzby. Objem hypotekárnych úverov sa vo všetkých krajinách Vyšehradskej štvorky okrem Mad'arskej republiky, počas sledovaného obdobia 2006 až 2016, neustále zvyšoval a úrokové sadzby klesali približne od roku 2009. Ked’že objem hypotekárnych úverov sa nachádzal väčšinou 
v nominálnom vyjadrení, mohol nastat' problém vplyvu d'alšej skrytej premennej a problém falošnej regresie. Preto bolo vhodné, aby sa objem hypotekárnych úverov prerátal na percentuálnu zmenu, aby bola dosiahnutá stacionárna časová rada. To znamená, že zmeny v časovej rade neboli v čase konštantné. Ďalšia z najvyšších dosiahnutých hodnôt bol vo vzt'ahu úrokových sadzieb hypotekárnych úverov a objemu hypotekárnych úverov v Slovenskej a Českej republike. Hodnoty korelačného koeficientu dosahovali úroveň 0,62 v Slovenskej republike a 0,6113 v Českej republike. S rastom úrokových sadzieb sa zvyšovala aj percentuálna zmena objemu hypotekárnych úverov oproti predchádzajúcemu roku rovnakého štvrt'roku. Tieto hodnoty neboli až tak vel'mi vysoké, nesplňovali ani stanovené kritérium preukázatel'nosti 0,7 , ale boli to najvyššie dosiahnutel'né hodnoty korelačného koeficientu v kapitole 2. Zároveň všetky hodnoty korelačného koeficientu boli overené testovacou štatistikou (t-testom), takže môžeme tvrdit', že všetky hodnoty korelačného koeficientu boli štatisticky významné.

Korelačná analýza, ktorá bola využitá v tomto článku potvrdila istý vzt'ah medzi úrokovými sadzbami hypotekárnych úverov a objemom hypotekárnych úverov a tiež aj vzt'ah úrokových sadzieb a miery inflácie. Tieto vzt’ahy spolu najsilnejšie korelovali, pričom to platilo pre skoro všetky krajiny Vyšehradskej štvorky. Vo všetkých prípadoch sa vyskytovala pozitívna závislost', to znamená, že vývoj jedného ukazovatel'a nasleduje pohyby druhého ukazovatel'a. Samozrejme ked' boli nízke úrokové sadzby hypotekárnych úverov, tak sa zvyšoval objem hypotekárnych úverov. Pretože boli hypotekárne úvery kvázi výhodné, ekonomike sa darilo, preto aj rôzne firmy žiadali o hypotekárne úvery aby mohli investovat'. Dôvod žiadostí o hypotekárny úver pre domácnosti, môže byt' aj ten, že chcú bývat' vo svojom alebo $\mathrm{v}$ lepšom bývaní. Aj vd'aka týmto dôvodom sa zvyšovali bankám hodnoty úverov a banky mohli vyvíjat' rôzne d'alšie bankové sprostredkovanie. Vyskytovali sa aj takí l'udia, ktorí mali až nad rámec finančných prostriedkov, a miesto toho aby im niekde peniaze ležali a podliehali inflácíi ich radšej niekde investovali a tým pádom banky prijímali vklady, za ktoré neskôr získajú príjem v podobe úrokov. Problematika závislosti teda korelácie umožňovala objavit' len silu tesnosti korelácie vzt'ahu dvoch alebo viacerých ukazovatel'ov. Korelačná analýza dokázala určit' len lineárny vzt'ah a nie viacrozmerné, alebo iné druhy závislosti, či smer kauzality. Táto problematika vyžaduje aplikáciu zložitejších štatistických a ekonometrických metód a preto by práve tento problém mohol byt' podnet na d'alšie spracovanie. Určite by v d'alšom vývoji mohla byt' preskúmaná dlhšia časová rada, nie len 10 rokov ale napríklad 15, pretože vel’a výskumníkov považuje práve $\mathrm{T}=50 \mathrm{za}$ dost' na to, aby nenastalo skreslenie významu korelácie. Vhodné časové periódy môžu byt' štvrt'ročné alebo mesačné. Čím dlhšia časová rada bude, tým bude menšia pravdepodobnost’ skreslenia výsledkov korelácie.

Z vývoja skúmaných makroekonomických ukazovatel'ov bolo vidiet', že kríza, ktorá nastala počas sledovaného obdobia mala vel'ký vplyv. Tento vplyv sa prejavil najmä pri miere nezamestnanosti a zmena je najviac viditel'ná rok po vypuknutí krízy, teda v roku 2009. Vtedy miera nezamestnanosti vo všetkých štyroch krajinách V4 dosahovala najvyššiu úroveň. Rast týchto ukazovatel'ov mal mat' negatívny dopad na objem hypotekárnych úverov. V prípade Mad'arskej republiky tomu tak naozaj bolo, ked'že sa Mad'arsko dostalo do recesie a tým, že sa znižoval hrubý domáci produkt vel'mi výrazne to ovplyvnilo vývoj objemu hypotekárnych úverov na trhu. V ostatných krajinách celkový objem hypotekárnych úverov počas krízového obdobia rástol ale pomalším tempom oproti predchádzajúcemu roku toho istého štvrt'roku. Mohlo to byt' spôsobené priaznivým vývojom hrubého domáceho produktu v ostatných krajinách Vyšehradskej štvorky. 


\section{Záver}

Primárnym ciel'om tohto článku bolo identifikovat' vplyv príslušných makroekonomických veličín na trh s hypotekárnymi úvermi, v Slovenskej republike, Českej republike, Pol'skej a Mad'arskej republike za obdobie 2006 až 2016.

Naplnenie stanoveného ciel’a bolo dosiahnuté za pomoci štatistických a ekonometrických metód, a teda s využitím korelačnej analýzy. Z vybraných makroekonomických ukazovatel'ov najviac ovplyvňovali objem hypotekárnych úverov úrokové sadzby hypotekárnych úverov. Tento vzt’ah bol očakávaný a vd’aka využitiu korelačnej analýzy, ktorá skúma závislost' dvoch a viacerých veličín, potvrdený v Slovenskej a Českej republike. Išlo o pozitívnu koreláciu a teda s rastom úrokových sadzieb rástla aj percentuálna zmena objemu hypotekárnych úverov. Ďalší najvyšší pozitívny koeficient korelácie bol nájdený vo vzt'ahu úrokových sadzieb hypotekárnych úverov a mierou inflácie. Tento koeficient korelácie bol dosiahnutý v Pol'skej a Slovenskej republike.

V rámci porovnania krajín je vidiet', že z pohl'adu úrokových sadzieb majú všetky štyri krajiny klesajúcu tendenciu, ale aj tak pomerne dost' vysoké úrokové sadzby sú v Mad'arskej republike v porovnaní s ostatnými krajinami V4. Preto aj objem hypotekárnych úverov je nižší oproti ostatným krajinám, pretože mad'arskí obyvatelia si o hypotekárne úvery žiadajú v cudzej mene.

\section{Literatura}

[1] BOUYON, S., 2013g. EMF - Quarterly Review Q4 2012. In: European Mortgage Federation [online]. [cit. 2017-05-05]. Dostupné z < http://www.hypo.org/DocShareNoFrame/docs/7/EKNDCAFCKCMADJMOIHFKNOHN PDW69DBDA6TE4Q/EMF/Docs/DLS/2013-00033.pdf>

[2] Eurostat. House price index. In: Eurostat [online]. [cit. 2017-05-05]. Dostupné z <http://appsso.eurostat.ec.europa.eu/nui/submitViewTableAction.do>

[3] ISGRO, L., 2014h EMF - Quarterly Review Q4 2013. In: European Mortgage Federation [online]. [cit. 2017-05-05]. Dostupné $\quad$ Z http://www.hypo.org/DocShareNoFrame/docs/4/EKNDCAFCKCMADJMOIHFKNOHN PDWK9DBDAKTE4Q/EMF/Docs/DLS/2014-00034.pdf>

[4] ISGRO, L., 2015i. EMF - Quarterly Review Q4 2014. In: European Mortgage Federation [online]. [cit. 2017-05-05]. Dostupné <http://www.hypo.org/DocShareNoFrame/docs/8/EKNDCAFCKCMADJMOIHFKNOH NPDW19DBDP6TE4Q/EMF/Docs/DLS/2015-00023.pdf>

[5] MCDOWELL, M. and A. SCIAMARELLI, 2008b. Quarterly Review 2007 - 4th Quarter. In: European Mortgage Federation [online]. [cit. 2017-05-05]. Dostupné z <http://www.hypo.org/DocShareNoFrame/docs/4/EKNDCAFCKCMADJMOIHFKNOH NPDBW9DBYAYTE4Q/EMF/Docs/DLS/2008-00131.pdf>

[6] MCDOWELL, M. and L. FIGA-TALAMANCA, 2007a. Quarterly Review 2006 - 4th Quarter. In: European Mortgage Federation [online]. [cit. 2017-05-05]. Dostupné z <http://www.hypo.org/DocShareNoFrame/docs/3/EKNDCAFCKCMADJMOIHFKNOH NPDB39DBYBNTE4Q/EMF/Docs/DLS/2007-00106.pdf>

[7] OECD. Inflation (CPI). In: OECD [online]. [cit. 2017-05-05]. Dostupné z <https://data.oecd.org/price/inflation-cpi.htm> 
[8] OECD. Unemployment rate. In: OECD [online]. [cit. 2017-05-05]. Dostupné z <https://data.oecd.org/unemp/unemployment-rate.htm>

[9] SCIAMARELLI, A. and S. YAVARI, 2010d. EMF Quarterly Review - Q4 2009. In: European Mortgage Federation [online]. [cit. 2017-05-05]. Dostupné z <http://www.hypo.org/DocShareNoFrame/docs/7/EKNDCAFCKCMADJMOIHFKNOH NPDWD9DBDC1TE4Q/EMF/Docs/DLS/2010-00085.pdf>

[10] SCIAMARELLI, A., 2011e. EMF - Quarterly Review Q4 2010. In: European Mortgage Federation [online]. [cit. 2017-05-05]. Dostupné z < http://www.hypo.org/DocShareNoFrame/docs/1/EKNDCAFCKCMADJMOIHFKNOHN PDWY9DBDTDTE4Q/EMF/Docs/DLS/2011-00070.pdf>

[11] SCIAMARELLI, A., 2012f. EMF - Quarterly Review Q4 2011. In: European Mortgage Federation [online]. [cit. 2017-05-05]. Dostupné z < http://www.hypo.org/DocShareNoFrame/docs/2/EKNDCAFCKCMADJMOIHFKNOHN PDWY9DBD2DTE4Q/EMF/Docs/DLS/2012-00050.pdf>

[12] SCIAMARELLI, A., 2009c. Quarterly Review 2008 - 4th Quarter. In: European Mortgage Federation [online]. [cit. 2017-05-05]. Dostupné z < http://www.hypo.org/DocShareNoFrame/docs/5/EKNDCAFCKCMADJMOIHFKNOHN PDBG9DBYPWTE4Q/EMF/Docs/DLS/2009-00128.pdf>

[13] STUCHLÍK, J., 2009. Pád Lehman Brothers: Co poslalo svět do finanční propasti. In: Penize.cz [online]. [cit. 2018-05-25]. Dostupné $\mathrm{z}<\mathrm{https} / / / \mathrm{www}$. penize.cz/svetovaekonomika/59054-pad-lehman-brothers-co-poslalo-svet-do-financni-propasti>

[14] WESTIG, D., 2017k. European Mortgage Federation Quarterly Review - Q4 2016. In: European Mortgage Federation [online]. [cit. 2017-05-05]. Dostupné $\mathrm{z}<$ http://www.hypo.org/DocShareNoFrame/docs/2/EKNDCAFCKCMADJMOIHFKNOHN PDW39DBDPNTE4Q/EMF/Docs/DLS/2017-00026.pdf>

[15] WESTIG, D., 2016j. European Mortgage Federation Quarterly Review - Q4 2015. In: European Mortgage Federation [online]. [cit. 2017-05-05]. Dostupné $\mathrm{z}<$ http://www.hypo.org/DocShareNoFrame/docs/9/EKNDCAFCKCMADJMOIHFKNOHN PDWN9DBDPGTE4Q/EMF/Docs/DLS/2016-00029.pdf> 